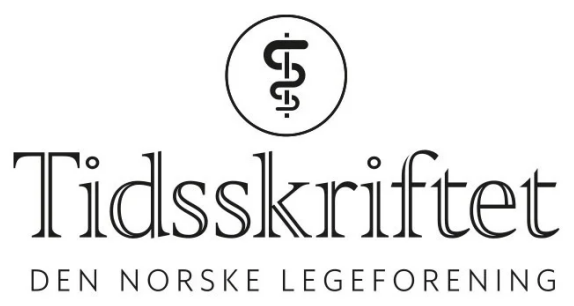

\title{
Den Gud gir et embete
}

BREV TIL REDAKTØREN

\section{KÅRE ERTRESVÅG}

Kåre Ertresvåg (f. 1940) er spesialist i generell kirurgi og overlege ved Diakonhjemmet Sykehus. Ingen oppgitte interessekonflikter.

Email: karearne@gmail.com 


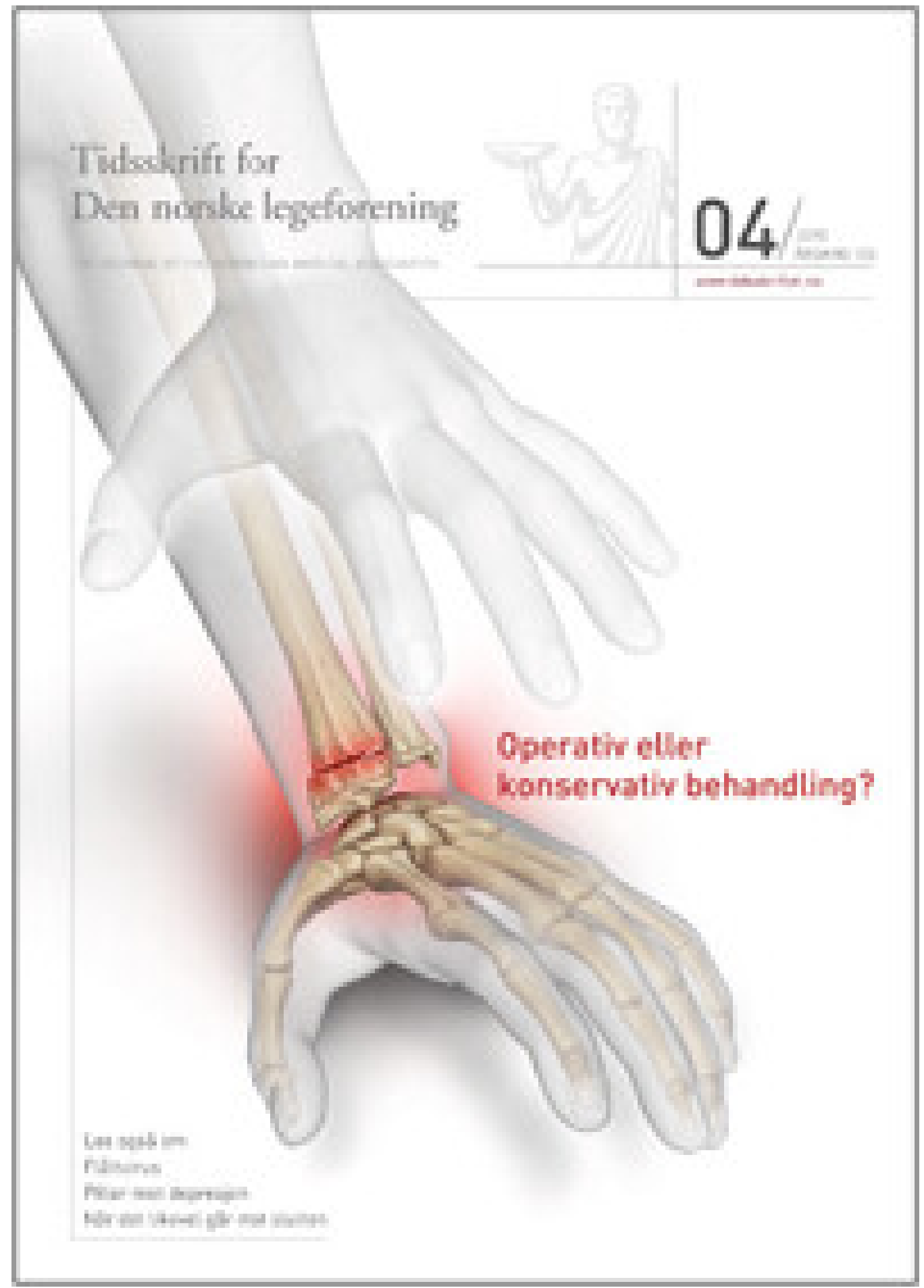

En artikkel i Tidsskriftet nr. 4/2012 omhandlet bl.a. ordspråket «Den Gud gir et embete, gir han også forstand» (1). Om det bare var så enkelt, ville jo det meste bli bra. Det kan imidlertid diskuteres om ordspråket egentlig er slik.

Elisabeth Swensen har hevdet at den opprinnelige ordlyden antakelig er «Den Gud giver et embede»... den give Han også forstand» - det vil si at ordspråket inneholder et imperativ snarere enn en påstand. Swensen mener forskjellen i betydning er "potensielt katastrofal» (2). Mot den ordinære forståelsen om at det automatisk følger klokskap med makt, setter Swensen bønnen om at den som får en betrodd stilling, også må få forstand. Jeg er enig med henne i at forskjellen er potensielt katastrofal dersom den som får embetet, tror at forstanden automatisk følger med, og/eller hvis den som utnevner, tror det samme.

Dette er en redigert versjon av et innlegg publisert som rask respons på nett 19.2. 2013 . http://tidsskriftet.no/article/2976306/ 
1. Lærum OD. Styring av vitenskap på ville veier. Tidsskr Nor Legeforen 2013; 133: 441-4.

2. Swensen E. Den Gud giver et embete... Hovedforelesning på primærmedisinsk uke 2012. http://elswense.wordpress.com/2012/12/o8/den-gud-giver-et-embede-hovedforelesning-paprimaermedisinsk-uke-2012/(19.2.2013).

Publisert: 23. april 2013. Tidsskr Nor Legeforen. DOI: 10.4045/tidsskr.13.0419

(C) Tidsskrift for Den norske legeforening 2023. Lastet ned fra tidsskriftet.no 26. april 2023. 